\title{
Structure of thermally evaporated bismuth selenide thin films
}

\author{
E.I.Rogacheva ${ }^{1}$, A.G.Fedorov ${ }^{2}$, S.I.Krivonogov ${ }^{2}$, \\ P.V.Mateychenko ${ }^{2}$, M.V.Dobrotvorskay ${ }^{2}$, A.S.Garbuz ${ }^{3}$, \\ O.N.Nashchekina ${ }^{1}$, A.Yu.Sipatov \\ ${ }^{1}$ National Technical University "Kharkov Polytechnic Institute", \\ 2 Kyrpychova St., 61002 Kharkiv,Ukraine \\ ${ }^{2}$ Institute for Single Crystals, National Academy of Sciences of Ukraine, \\ 60 Nauky Ave., 61001 Kharkiv, Ukraine \\ ${ }^{3}$ B.Verkin Institute for Low Temperature Physics and Engineering, \\ 47 Nauky Ave., 61103 Kharkiv, Ukraine
}

Received 4 April, 2018

The $\mathrm{Bi}_{2} \mathrm{Se}_{3}$ thin films with thicknesses $d=7-420 \mathrm{~nm}$ were grown by thermal evaporation in vacuum of stoichiometric $n-\mathrm{Bi}_{2} \mathrm{Se}_{3}$ crystals onto heated glass substrates under optimal technological conditions determined by the authors. The growth mechanism, microstructure, and crystal structure of the prepared thin films were studied using X-ray diffraction, scanning electron microscopy, energy-dispersive X-ray spectroscopy, X-ray photoelectron spectroscopy, and atomic force microscopy. It was established that the prepared thin films were polycrystalline, with composition close to the stoichiometric one, did not contain any phases apart from $\mathrm{Bi}_{2} \mathrm{Se}_{3}$, were of a high structural quality, and the preferential growth direction [001] corresponded to the direction of a trigonal axis $C_{3}$ in a hexagonal lattice. The films, like the initial crystal, exhibited $n$-type conductivity. It was shown that with increasing film thickness, the grain size and the film roughness remain practically the same at thicknesses $d<100 \mathrm{~nm}$, and after that increase, reaching their saturation values at $d \sim 300 \mathrm{~nm}$. It follows from the results obtained in this work that using the method of thermal evaporation in vacuum from a single source, one can prepare thin $n-\mathrm{Bi}_{2} \mathrm{Se}_{3}$ films of a sufficiently high structural quality with a composition close to the stoichiometric one and the preferential growth orientation.

Keywords: bismuth selenide, thermal evaporation, glass substrates, thin films, thickness, crystal structure, crystal morphology, grain size, roughness, preferential orientation.

Тонкие пленки $\mathrm{Bi}_{2} \mathrm{Se}_{3}$ с толщинами $d=7-420$ нм выращены методом термического испарения в вакууме кристаллов стехиометрического $n-\mathrm{Bi}_{2} \mathrm{Se}_{3}$ на нагретые стеклянные подложки. Исследованы механизм роста, микроструктура и кристаллическая структура приготовленных пленок методами рентгеновской дифрактометрии, сканирующей электронной микроскопии, энергодисперсионной рентгеновской спектроскопии, фотоэлектронной рентгеновской спектроскопии и атомной силовой микроскопии. Установлено, что приготовленные тонкие пленки - поликристаллические, имеют состав, близкий к стехиометрическому, не содержат других фаз, кроме $\mathrm{Bi}_{2} \mathrm{Se}_{3}$, высокого структурного качества, преимущественное направление роста - направление [001] соответствует направлению тригональной оси $C_{3}$ в гексагональной решетке. Пленки, как и исходный кристалл, имеют $n$-тип проводимости. Показано, что с увеличением толщины пленки размер зерна и шероховатость остаются постоянными при толщинах $d<100$ нм, а затем возрастают, достигая насыщения при $d \sim 300$ нм. Из полученных результатов следует, что, используя метод термического испарения в вакууме из одного 
источника, можно приготовить тонкие $n-\mathrm{Bi}_{2} \mathrm{Se}_{3}$ пленки достаточно высокого структурного качества с составом, близким к стехиометрическому, и с преимущественным направлением роста.

Структура тонких плівок селеніду вісмуту, одержаних термічним випаровуванням у вакуумі. О.І.Рогачова, О.Г.Федоров, С.І.Кривоногов, П.В.Матейченко, М.В.Добротворська, О.С.Гарбуз, О.М.Нащекіна, О.Ю.Сипатов.

Тонкі плівки з товщинами $d=7-420$ нм вирощені методом термічного випаровування у вакуумі кристалів стехіометричного $n-\mathrm{Bi}_{2} \mathrm{Se}_{3}$ на нагріті скляні підкладки при оптимальних технологічних умовах. Досліджено механізм росту, мікроструктуру та кристалічну структуру виготовлених плівок з використанням методів рентгенівської дифрактометрії, скануючої електронної мікроскопії, енергодисперсійної рентгенівської спектроскопії, фотоелектронної рентгенівської спектроскопії та атомної силової мікроскопії. Встановлено, що виготовлені тонкі плівки є полікристалічними, мають склад, близький до стехіометричного, не одержують інших фаз, окрім $\mathrm{Bi}_{2} \mathrm{Se}_{3}$, високої структурної якості, переважний напрямок росту - напрямок [001] відповідає напрямку тригональної осі $C_{3}$ у гексагональній решітці. Плівки, як і вихідний кристал, мають n-тип провідності. Показано, що зі збільшенням товщини плівки розмір зерна і шорсткість залишаються постійними при товщині $d<100$ нм, потім зростають, досягаючи насичення при $d \sim 300$ нм. 3 отриманих результатів випливає, що, використовуючи метод термічного випаровування у вакуумі з одного джерела, можна приготувати тонкі $n-\mathrm{Bi}_{2} \mathrm{Se}_{3}$ плівки досить високої структурної якості зі складом, близьким до стехіометричного, і з переважним напрямком росту.

\section{Introduction}

The $\mathrm{V}_{2} \mathrm{VI}_{3}$ semiconductors $\mathrm{Bi}_{2} \mathrm{Te}_{3}, \mathrm{Bi}_{2} \mathrm{Se}_{3}$, $\mathrm{Sb}_{2} \mathrm{Te}_{3}$ and solid solutions formed between these compounds belong to the best low-temperature thermoelectric materials most widely used in manufacturing of various cooling devices [1-3]. The growing interest in the low-dimensional nanostructures based on these compounds [4,5] stimulates detail studies of the properties of these materials in the thin-film state. In recent years, the interest in studying the $\mathrm{V}_{2} \mathrm{VI}_{3}$ crystals and thin films has further increased after it was established by angle-resolved photoemission spectroscopy that $\mathrm{Bi}_{2} \mathrm{Te}_{3}, \mathrm{Bi}_{2} \mathrm{Se}_{3}$ and $\mathrm{Sb}_{2} \mathrm{Te}_{3}$ exhibit properties of $3 \mathrm{D}$-topological insulators, which represent dielectrics with a gapless metallic surface layer with a Dirac dispersion law [6, 7]. The fact that in thin films, the relative contribution of the surface layer to the total conductivity is larger than in bulk crystals, facilitates the observation of special properties of topological objects and thus further stimulates studies of the $\mathrm{V}_{2} \mathrm{VI}_{3}$ thin films. There have appeared works pointing out the relation between topological and thermoelectric properties and the possibility of using principally new ways of enhancing thermoelectric figure of merit [8-10].

A necessary condition for studying the specificity of the topological layer properties in thin films is a high structural quality of the films, which would make it possible to exclude the influence of defects of different types veiling the manifestation of topological nature of the surface layer. On the other hand, it is well known that in thin films with thicknesses comparable to the de Broglie wavelength, quantum size effects can take place $[11,12]$. They can manifest themsel ves, in particular, through an oscillatory character of the dependences of transport characteristics on the thin film thickness $[12,13]$, and investigation of those dependences can provide additional information about the proper ties of the topological metallic layer [14]. Size quantization of energy spectrum can be studied either in monocrystalline films, or in polycrystalline films with certain preferred orientation of crystallites [12]. That is why before studying the transport properties of polycrystalline thin films, it is necessary to determine the direction of crystallite growth in these films. In [15, 16], it was shown that using the method of thermal evaporation in vacuum of $p-$ and $n-\mathrm{Bi}_{2} \mathrm{Te}_{3}$ crystals onto glass substrates and selecting optimal technological parameters $[17,18]$, one can prepare polycrystalline thin $p-$ and $n-\mathrm{Bi}_{2} \mathrm{Te}_{3}$ films with the crystal structure of sufficiently high quality and preferred orientation of crystallites. It is of interest to carry out similar studies for $\mathrm{Bi}_{2} \mathrm{Se}_{3}$ thin films.

It is known that the $\mathrm{Bi}_{2} \mathrm{Se}_{3}$ compound melts congruently at $978 \mathrm{~K}$ with an open maximum, which is deviated from the stoichiometric composition in the direction of excess bismuth and is located at $40.02 \pm 0.1$ at. $\%$ Bi $[2,3]$. Prevailing charged defects in this compound are once 
and twice ionized vacancies of Se atoms, and that is why at room temperature $\mathrm{Bi}_{2} \mathrm{Se}_{3}$ samples always exhibit $n$-type conductivity. The $\mathrm{Bi}_{2} \mathrm{Se}_{3}$ semiconductor compound crystallizes in a rhombohedral structure (space group $R 3 m-D_{3 d}^{5}$ ), with 5 atoms per unit cell $[2,3]$. The structure is composed of fivelayer packets (quintets) $-\mathrm{Se}^{1}-\mathrm{Bi}-\mathrm{Se}^{2}-\mathrm{Bi}-\mathrm{Se}^{1}$ ( 1 and 2 indexes denote different positions of Se atoms in the crystal lattice), perpendicular to the trigonal $C_{3}$ axis. $\mathrm{Bi}_{2} \mathrm{Se}_{3}$ has a larger band gap than $\mathrm{Bi}_{2} \mathrm{Te}_{3}[1,2]$, which expands possibilities for exploring the properties of a topological layer, since charge carrier concentration in the interior of the film is lower and, consequently, its contribution to conductivity is smaller.

The $\mathrm{Bi}_{2} \mathrm{Se}_{3}$ thin films can be prepared by various methods. Among them are: thermal evaporation in vacuum [19-27], molecular beam epitaxy (MBE) [28-34], magnetron sputtering [35], pulsed laser deposition [36], chemical deposition [37-39], electrodeposition [40], the SILAR method [41], etc. The $\mathrm{Bi}_{2} \mathrm{Se}_{3}$ thin films can be grown on amorphous substrates (glass, $\mathrm{SiO}_{2}$ etc.) and monocrystalline ones ( $\mathrm{Si}(111), \mathrm{Al}_{2} \mathrm{O}_{3}, \mathrm{KBr}$, CdS, $\mathrm{SrTiO}_{3}(111), \mathrm{GaAs}, \mathrm{InP}$, etc.).

The methods of thermal evaporation in vacuum include the thermal evaporation from a single source $\left(\mathrm{Bi}_{2} \mathrm{Se}_{3}\right.$ crystals) [2127] and thermal co-evaporation from two sources (Bi and $\mathrm{Se})[19,20]$. The films prepared using those methods were reported to be polycrystalline [19-27]. In [23, 24, 26, $27]$, it was established that under thermal evaporation from a single source and deposition onto a glass substrate at room temperature, as-deposited films are amorphous and can be transformed into crystalline ones by annealing at a certain temperature [22]; hovewer, no information regarding the preferential orientation of film growth for these methods was provided. When other methods of thin film preparation were used, films were usually grown on monocrystalline substrates, and to bring the films to an equilibrium state, they were either deposited onto heated substrates or subjected to annealing after deposition onto cold substrates. The preferential orientation of growth usually corresponded to the [001] direction. Using the MBE method, the authors of [28] succeeded in growing $\mathrm{Bi}_{2} \mathrm{Se}_{3}$ thin films of a high structural quality with a high degree of order along the trigonal axis not on monocrystalline but on amorphous $\left(\mathrm{SiO}_{2}\right)$ substrates. The characterization of those films by angle resolved photoemission spectroscopy showed the existence of the surface topological states in the studied films, despite the absence of the in-plane rotational order of domains. There arises a question whether it is possible to grow preferentially oriented $\mathrm{Bi}_{2} \mathrm{Se}_{3}$ thin films of a high structural quality on amorphous substrates using relatively simple and low-cost method of thermal evaporation in vacuum. Encouraging is the fact that, as was mentioned above, the authors of $[15,16]$ succeeded in obtaining high-quality $\mathrm{Bi}_{2} \mathrm{Te}_{3}$ films using thermal evaporation in vacuum from a single source.

The goal of the present work is to investigate the possibility of growing preferentially oriented thin $\mathrm{Bi}_{2} \mathrm{Se}_{3}$ films of a high quality structure, with reproducible composition and $n$-type of conductivity on amorphous glass substrates using the method of thermal evaporation in vacuum from a single source $\left(\mathrm{Bi}_{2} \mathrm{Se}_{3}\right.$ polycrystals).

As a result of the study, it was established that using the method of thermal evaporation in vacuum of stoichiometric $n-\mathrm{Bi}_{2} \mathrm{Se}_{3}$ crystals onto glass substrates and selecting optimal technological parameters, one can obtain high quality polycrystalline thin $\mathrm{Bi}_{2} \mathrm{Se}_{3}$ films with the preferential orientation of crystallites along the trigonal axis [001], with compositions close to the stoichiometric one, exhibiting $n$-type conductivity, like the initial crystal.

\section{Experimental}

To prepare thin $n-\mathrm{Bi}_{2} \mathrm{Se}_{3}$ films, $n-\mathrm{Bi}_{2} \mathrm{Se}_{3}$ polycrystals of the stoichiometric composition were used as the initial material. The $\mathrm{Bi}_{2} \mathrm{Se}_{3}$ polycrystals were synthesized by direct fusion of high purity (99.999 at. \% of the main component) $\mathrm{Bi}$ and $\mathrm{Se}$ in evacuated quartz ampoules at the temperature $(1020 \pm 10) \mathrm{K}$ for $5-6 \mathrm{~h}$ and subsequent annealing at $670 \mathrm{~K}$ for $300 \mathrm{~h}$. Taking into account the results of our earlier works, in which we refined the method of growing $\mathrm{Bi}_{2} \mathrm{Te}_{3}$ films by thermal evaporation in vacuum from a single source [15-18], as well as the existing literature on growing thin $\mathrm{Bi}_{2} \mathrm{Se}_{3}$ films by different methods and, first of all, by thermal evaporation in vacuum, we selected optimal technological parameters allowing us to prepare $\mathrm{Bi}_{2} \mathrm{Se}_{3}$ thin films of a high structural quality and preferred growth orientation. The films with thicknesses $d=7-420 \mathrm{~nm}$ were grown by thermal evaporation of a stoichiometric $n-\mathrm{Bi}_{2} \mathrm{Se}_{3}$ polycrystal in vacuum $\left(\sim 10^{-5} \mathrm{~Pa}\right)$ 
from a tungst en boat in which $1-3 \mathrm{~g}$ of the initial material was placed and subsequent deposition onto flat glass substrates, wellcleaned before deposition sequentially by hydrochloric acid, distilled water and $95 \%$ alcohol, and heated to the temperature $T_{S}=$ $500 \mathrm{~K}$. The condensation rate was $0.1-$ $0.3 \mathrm{~nm} / \mathrm{s}$. When the condensation process is finished, the samples were cooled to room temperature and removed from the vacuum chamber in air.

The thickness of the films were controlled by a calibrated quartz resonator. The crystal structure, phase composition, and preferential growth direction of the films were determined by XRD on the diffractometer DRON-2 using CuK $\alpha$-radiation. The chemical composition, degree of homogeneity, grain structure, and morphology of the films were examined by electron probe microanalysis using a scanning microscope SEM (JSM-6390LV (Jeol Ltd., Japan) equipped with an Energy-Dispersive X-ray spectrometer (EDS) X-max N 50. X-ray spectra were recorded within a scan area of $0.01 \mathrm{~mm}^{2}$ with a step of $1 \mathrm{~mm}$ at accelerating voltage $10 \mathrm{kV}$. The morphology of the film surface, grain size, and roughness were investigated using atomic force microscopy (AFM) Solver Pro NT-MDT. The composition of the surface layer of the samples was examined by X-ray photoelectron spectroscopy (XPS) on a XPS-800 Kratos spectrometer using $A / K_{\alpha}$-radiation and hemispheric electrostatic analyzer. The photoelectrons were excited by MgK $\alpha$-radiation ( $h \gamma=$ $1253.6 \mathrm{eV})$. The thickness of the analyzed layer was $5 \mathrm{~nm}$. The composition of the sample surface was determined from the line area ratios of $\mathrm{Bi} 4 \mathrm{f}$ and Se3d, core-shells taking into account sensitivity factors. The conductivity type of the obtained thin films was determined by the Hall coefficient $R_{H}$ and Seebeck coefficient $S$ signs. $S$ was measured by a compensation method relative to copper electrodes in the direction parallel to the film surface with an error not exceeding $\pm 3 \%$, and $R_{H}$ was measured in a magnetic field of $1 \mathrm{~T}$ with an accuracy of $\pm 5 \%$. All structural studies were carried out on freshly prepared samples at room temperature, which allowed us to exclude a possible effect of the oxidation processes on the crystal structure and morphology of the samples.

\section{Results and discussion}

In Fig. 1a, the diffraction pattern of $n-\mathrm{Bi}_{2} \mathrm{Se}_{3}$ polycrystal which was used as the initial material for the thin film preparation is presented. The polycrystal had a rhombohedral structure and all lines in the diffraction pattern corresponded to the reference values given in the ASTM standards [42] for $\mathrm{Bi}_{2} \mathrm{Se}_{3}$. No additional phases were detected. In Figs. 1,b-f, X-ray diffraction patterns of the obtained thin films with different thicknesses are shown. It is seen from the diffraction patterns that the films have a crystalline structure, all diffraction peaks correspond to the $\mathrm{Bi}_{2} \mathrm{Se}_{3}$ compound, and there are no peaks from other phases. All peaks are narrow, which indicates a high crystal quality of the films. It is seen from Figs. 2, b-d that for the films with thicknesses less than $d \sim 100 \mathrm{~nm}$, the intensities of $\left(\begin{array}{lll}0 & 0 & 3\end{array}\right),\left(\begin{array}{lll}0 & 0 & 6\end{array}\right),\left(\begin{array}{lll}0 & 0 & 15\end{array}\right),\left(\begin{array}{lll}0 & 0 & 18\end{array}\right)$ and $\left(\begin{array}{ll}0 \\ 0\end{array}\right.$ $021)$ peaks are more than twice as large as those for bulk crystal, whereas peaks corresponding to other crystallographic planes almost completely disappear. The substantial increase in the intensities of the peaks corresponding to the above mentioned planes in comparison with other peaks in the diffraction pattern indicates the presence of the preferred direction of crystallite growth - [001]. The authors of [43, 44], who investigated the mechanism of growth of thin $\mathrm{Bi}_{2} \mathrm{Te}_{3}$ films on amorphous substrates, attributed the formation of a texture in the direction [001] to a higher mobility of atoms on amorphous substrates than on crystalline ones. As a result, the state of equilibrium corresponding to the formation of a texture is reached more rapidly on amorphous substrates. Besides, from the point of view of the authors of [43, 44], one should also take into account the peculiarities of the epitaxial growth of layer-like structures with van der Waals bonding and the absence of dangling bonds on the substrate surface [45], because both these factors stimulate the alignment of layers with van der Waals bonds along the film surface, which results in the arrangement of crystallites in the [001] direction [43, 44]. A pronounced anisotropy of the growth rate leads to more rapid in-plane growth of crystallites, which proves to be 5 to 10 times as intensive as the growth in the direction perpendicular the film surface. In the diffraction patterns for the films with thicknesses greater than $d \sim 100 \mathrm{~nm}$ (Fig. 1,e,f), together with $\left(\begin{array}{lll}0 & 0 & 1\end{array}\right)$ lines, weak peaks from 

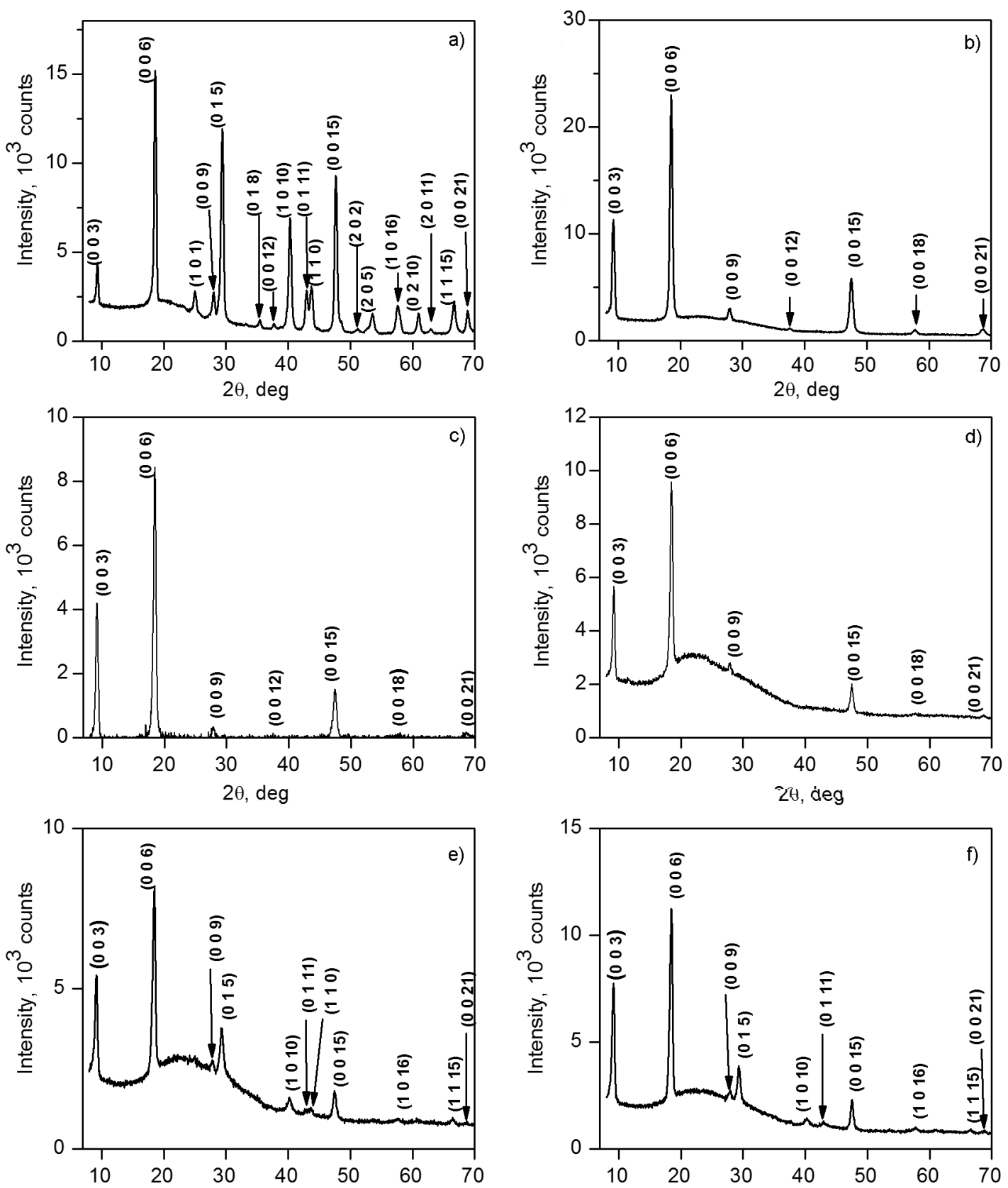

Fig. 1. X-ray diffraction patterns for the initial bulk bismuth selenide polycrystal (a) and for the thin films of the different thicknesses $d$ prepared from this polycrystal: $d=20 \mathrm{~nm}(\mathrm{~b}), 40 \mathrm{~nm}(\mathrm{c})$, $60 \mathrm{~nm}(\mathrm{~d}), 140 \mathrm{~nm}$ (e), $210 \mathrm{~nm}$ (f).

crystallographic planes other than $\left(\begin{array}{lll}0 & 0 & 1\end{array}\right)$ : $\left(\begin{array}{lll}0 & 1 & 5\end{array}\right),\left(\begin{array}{lll}1 & 0 & 10\end{array}\right),\left(\begin{array}{lll}0 & 1 & 11\end{array}\right),\left(\begin{array}{lll}1 & 0 & 16\end{array}\right)$ and $\left(\begin{array}{l}1 \\ 1\end{array}\right.$ 1 15) appear. This indicates a slight crystallite disorientation and probably results from an increase in the dislocation density and accumulation of stress. Nevertheless, the intensities of the (llll $\left.\begin{array}{lll}0 & 0 & 1\end{array}\right)$ peaks for all films almost do not change, which indicates the absence of any substantial disorientation in the texture direction. The fact that the diffraction patterns for the films with thick- nesses greater than $d \sim 100 \mathrm{~nm}$ (Fig. 1, e,f) are practically identical shows that the film thickness does not have any significant effect of on texture.

In Fig. 2, the results of the studies of the film surface using the AFM method are presented. The profilograms of the film surfaces for the films of various thicknesses are shown. As can be seen, the films consist of individual grains, mainly of a hexagonal shape, indicating their orientation in the 

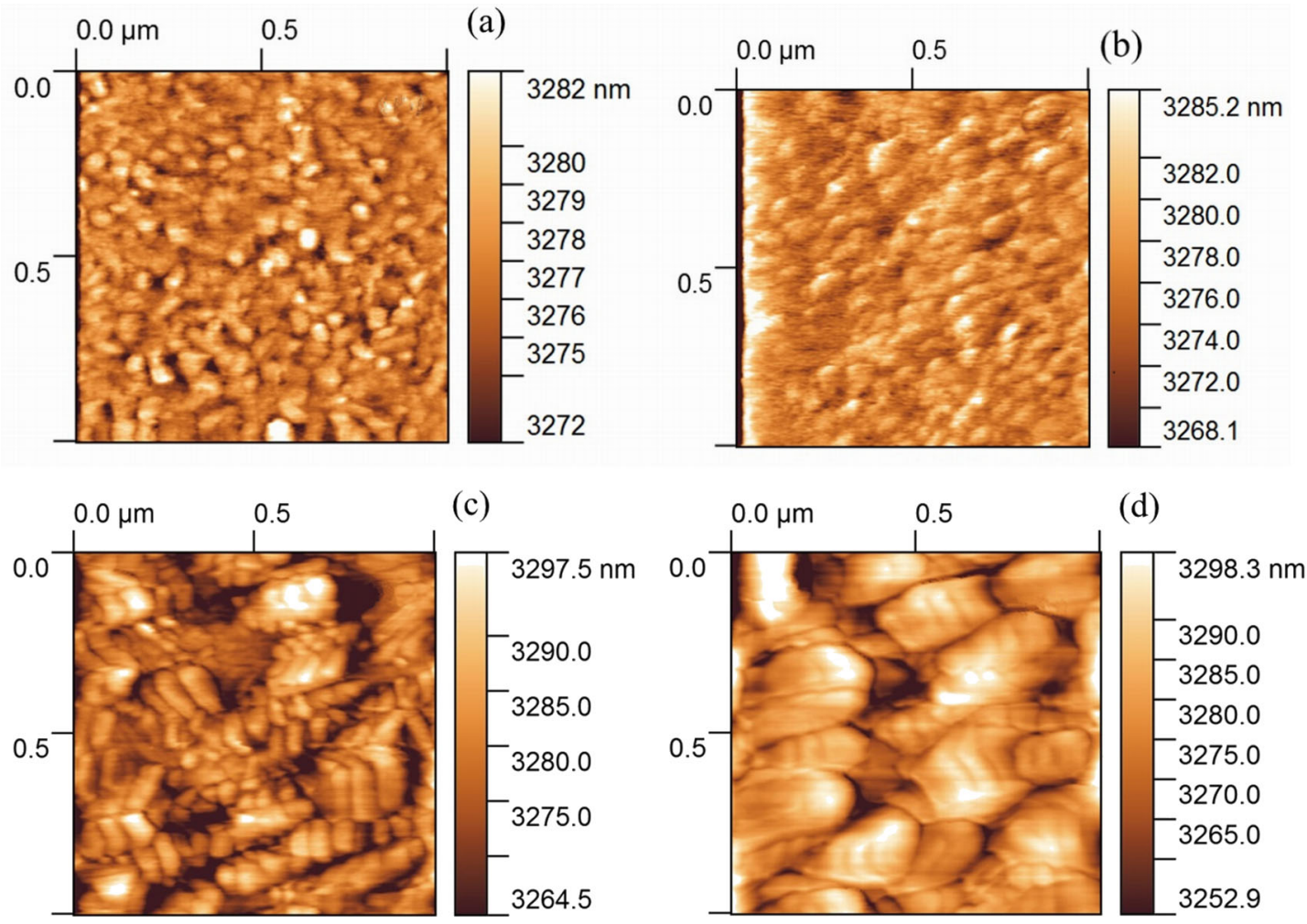

Fig. 2. Profilograms of the surface of the $\mathrm{Bi}_{2} \mathrm{Se}_{3}$ thin films with thicknesses: $d=7 \mathrm{~nm}, 1 \times 1 \mu \mathrm{m}(\mathrm{a})$; $d=25 \mathrm{~nm}, 1 \times 1 \mu \mathrm{m}(\mathrm{b}) ; d=180 \mathrm{~nm}, 1 \times 1 \mu \mathrm{m}(\mathrm{c}) ; d=265 \mathrm{~nm}, 1 \times 1 \mu \mathrm{m}(\mathrm{d})$.

[001] direction, perpendicular to the film surface. The results of the AFM studies are in good agreement with the results of X-ray diffraction analysis (Fig. 2). They show that there are no inclusions of the extraneous phases. The average grain size increases with increasing film thickness.

Studies of thin films using the SEM method (Fig. 3) confirmed that the films are polycrystalline and they contain no inclusions of a second phase. The average grain size grows as the film thickness increases, which is consistent with the AFM results. The photo in Fig. 3 shows the morphology of the film and a fresh cleavage in the secondary electron regime with the sample tilted at 70-80 degrees. The energy-dispersive X-ray spectroscopy study, both in the surface scanning and in the point to point probing modes, demonstrated that all films were characterized by a sufficiently high degree of uniformity. The compositions of the initial polycrystal and the grown films were close (within the range of error of the energy-dispersive X-ray spectroscopy method): the ratio of the atomic concentrations of $\mathrm{Bi}$ and $\mathrm{Se}$ for the initial stoichiometric $n-\mathrm{Bi}_{2} \mathrm{Se}_{3}$ crystal is $\mathrm{Bi} / \mathrm{Se}=$ 0.6667 and for the film with $d=290 \mathrm{~nm}$ it was is $\mathrm{Bi} / \mathrm{Se}=0.6686 \pm 0.05$. According to the XPS results, the ratio of the atomic concentrations of $\mathrm{Bi}$ and $\mathrm{Se}$ at the film surface was $\mathrm{Bi} / \mathrm{Se}=0.7 \pm 0.1$. In the freshly prepared films, whose structure was investigated, $\mathrm{Bi}$ and $\mathrm{Se}$ oxides were practically absent, however after the films were exposed to air for two years, XPS studies showed that although the ratio of the atomic concentrations of $\mathrm{Bi}$ and Se remained the same (Bi/Se $=0.7 \pm 0.1)$, the surface layer contained $\mathrm{Se}$ oxides (Bi oxides were absent). The similarity of the compositions of the grown films and the initial $n-\mathrm{Bi}_{2} \mathrm{Se}_{3}$ crystal was additionally confirmed by the closeness of the values of the Seebeck coefficient $S$ for the crystal and "thick" films. The value of $S$ for the bulk crystal was compared with that for the films of large thicknesses in order to exclude the possible classical size effect associated with a change in the relative contribution of surface states to conductivity under changing film thickness.

In Fig. 4, the dependences of the crystallite size $D$ and the root mean square roughness of the film surface $h$, determined in the $\operatorname{AFM}(D, h)$, SEM $(D)$, and XRD $(h)$ studies, on the film thickness, are presented. As 

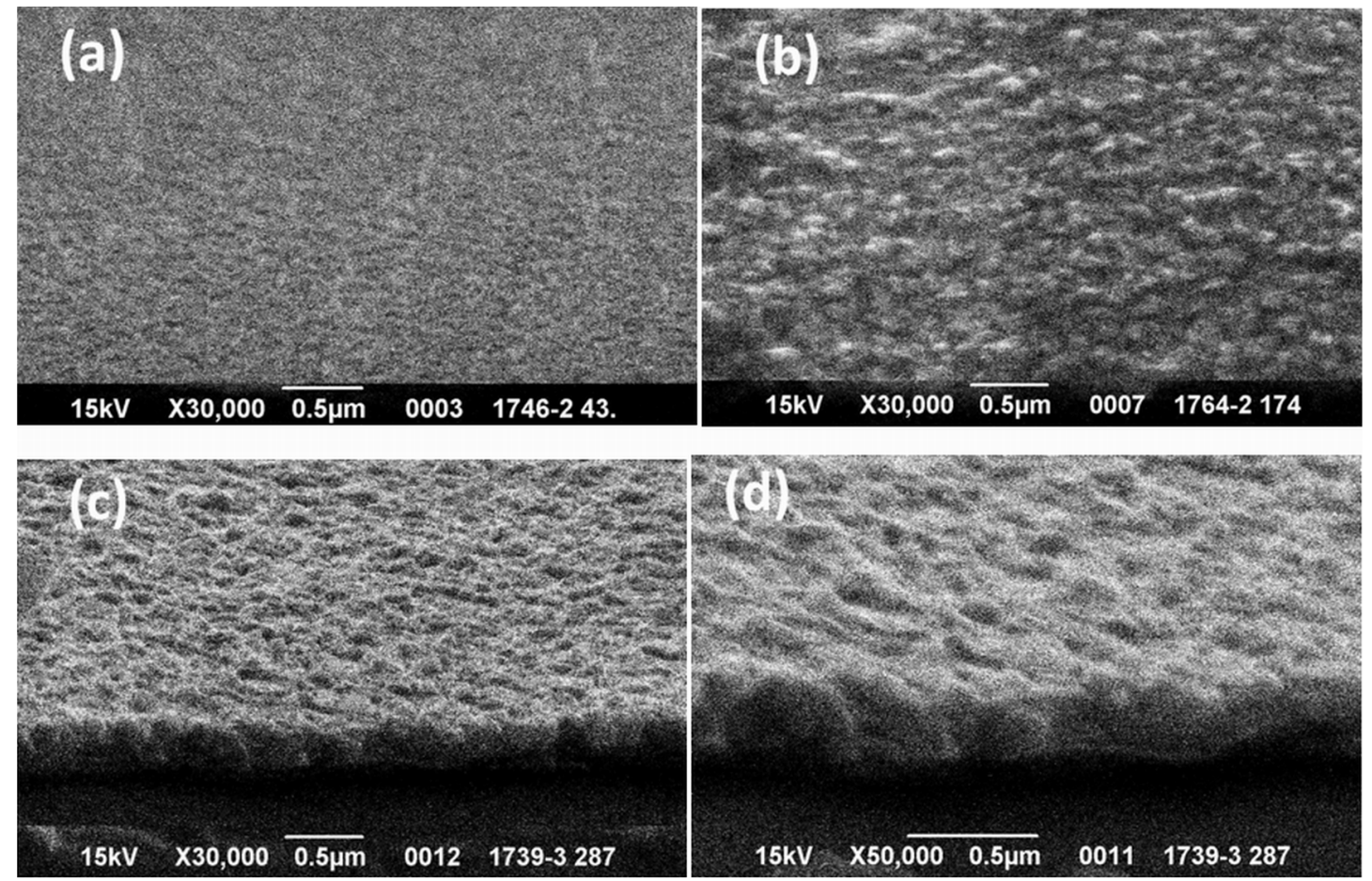

Fig. 3. SEM surface $(\mathrm{a}, \mathrm{b})$ and cross-section $(\mathrm{c}, \mathrm{d})$ images of the $\mathrm{Bi}_{2} \mathrm{Se}_{3}$ thin films with thicknesses $d=43 \mathrm{~nm}(\mathrm{a}), d=174 \mathrm{~nm}(\mathrm{~b}), d=287 \mathrm{~nm}\left(\mathrm{c}, \mathrm{d}-\right.$ tilt angle $\left.70^{\circ}\right)$.

is seen, up to $d \sim 100 \mathrm{~nm}$ the grain size and roughness practically do not change, amounting to $D \sim 75 \mathrm{~nm}$ and $h \sim 2.5 \mathrm{~nm}$, but with further increase in the film thickness to $d \sim 300 \mathrm{~nm}$, the values of $D$ and $h$ increase sharply, reaching $D \sim 270 \mathrm{~nm}$ and $h \sim 10 \mathrm{~nm}$, and after that, under further increase in $d, D$ and $h$ remain practically constant. The values of the crystallite size $D$ estimated by the SEM and the AFM methods are almost the same.

Likewise, the estimates of roughness $h$ by the AFM and the XRD methods are very close.

The increase in $D$ with increasing thickness of films deposited onto heated substrates is connected to all appearances with the recrystallization processes, i.e. the growth of some grains (crystallites) at the expense of others, taking place in the film during condensation. As result of recrystallization, a change to a new more thermodynamically stable state occurs due to the reduction in the total area of grain boundaries. Since from a thermodynamic point of view a spontaneous growth of grains in a homogeneous polycrystalline material is caused by a decrease in the total energy of the system in the process of recrystallization, when the size of larger grains grows due to the disappearance of some fine

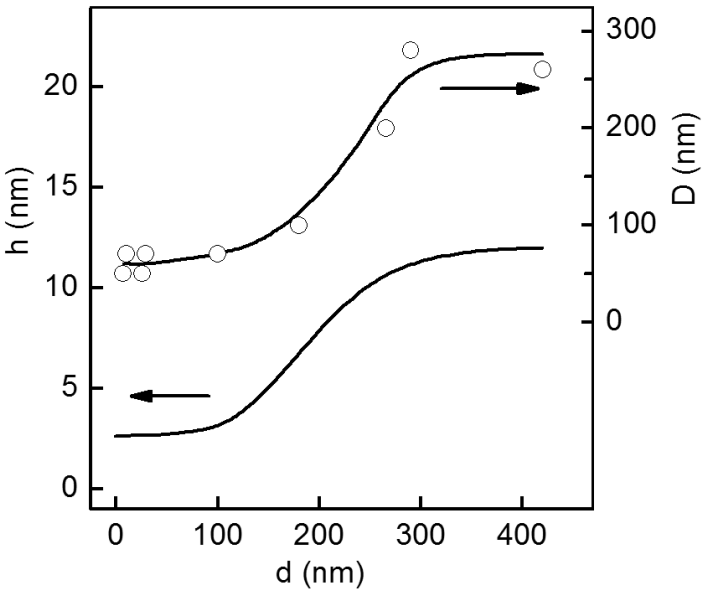

Fig. 4. Grain size $D$ and roughness $h$ as functions of the thin $n-\mathrm{Bi}_{2} \mathrm{Se}_{3}$ film thickness $d$.

grains. Other things being equal, a finegrained structure has excess energy as compared with a large-grained one. The recrystallization temperature $T_{R}$, i.e. the temperature at which the recrystallization processes start, depends on a large number of factors but in materials science it is often estimated as $T_{R} \sim 0.4 T_{M}$, where $T_{M}$ is the melting temperature, although such estimate is very rough and used mainly for metallic alloys [46] Using this approach we 
get the recrystallization temperature $T_{R}$ for $\mathrm{Bi}_{2} \mathrm{Te}_{3} \sim 400 \mathrm{~K}$ (the melting temperature for $\mathrm{Bi}_{2} \mathrm{Te}_{3}$ is $T_{M}=978.2 \mathrm{~K}$ ), and it seems that the substrate temperature $T_{S}$ is sufficient for the recrystallization processes to occur. However, it should be taken into account that temperature is not the only factor determining the size of grains during recrystallization. Another factor is the duration of heating. In our case, the substrate temperature $T_{S}$ remain constant, but with increasing film thickness, the time the film stays on the heated substrate, i.e. the duration of heating, increases. It follows from Fig. 4 that at thicknesses smaller than $\sim 100 \mathrm{~nm}$, an increase in $d$ does not lead to a growth in the grain size, i.e. the recrystallization processes do not start yet, although the substrate temperature $T_{S}=500 \mathrm{~K}$ is higher than the recrystallization temperature $T_{R}$. Obviously, the exposure time at $T_{S}$, necessary to obtain films up to $\sim 100 \mathrm{~nm}$ thick, is not sufficient for complete diffusion and growth of some crystalline grains of polycrystals at the expense of others, thus the grain size remains practically unchanged.

It also follows from Fig. 4 that at a certain film thickness $(\sim 100 \mathrm{~nm})$, which corresponds to a definite duration of heating at $T_{S}$, the rate of recrystallization, i.e. the rate with which the system reaches a thermodynamic equilibrium, starts to increase dramatically (in a sense, it can be considered a non-equilibrium phase transition), and the grain size starts to grow quickly. The subsequent constancy of the grain size at thicknesses 300-400 $\mathrm{nm}$ may indicate either a transition of the system into a stable equilibrium state, or a transition into an intermediate equilibrium state, after which the system may achieve a higher level of order under further increase in the film thickness, which plays the role of the critical parameter. A growing film is an example of a dissipative system, which is characterized by a constant energy inflow (under the heating of the substrate).

The observed increase in the roughness of films (Fig. 4) after increasing their $d$ greater than $d \sim 100 \mathrm{~nm}$ can be attributed to the appearance of a slight disorientation of the crystallites, which in turn is due to an increase in the density of dislociations and the accumulation of stresses in the film (see above).

It is known that in the process of alloy recrystallization, not only the size of grains but also the crystallographic orientation of crystallites can change. In the case of thin films it means that at a fixed substrate temperature at a certain $d$, a change in the preferential orientation becomes thermodynamically beneficial. We observed the change in the preferential growth direction from [001] to [015] under increasing $d$ in $n-\mathrm{Bi}_{2} \mathrm{Te}_{3}$ thin films [16]. It can be assumed that a similar phenomenon can be observed under a change in other parameter important for recrystallization - temperature. For example, in [47], the authors registered a change in the preferential orientation of crystallites under changing substrate temperature.

\section{Conclusions}

The thin $n-\mathrm{Bi}_{2} \mathrm{Te}_{3}$ films with thicknesses $d=7-420 \quad \mathrm{~nm}$ were grown by thermal evaporation in vacuum of stoichiometric $n-\mathrm{Bi}_{2} \mathrm{Te}_{3}$ crystals onto glass substrates heated to the temperature $T_{S}=500 \mathrm{~K}$. The crystal structure and microstructure of the freshly prepared films were characterized using the X-ray diffraction, energy-dispersive X-ray spectroscopy, scan electron microscopy, and atomic force microscopy methods.

It was established that the composition of the prepared films corresponded rather well to the initial material composition, and the films did not contain any phases apart from the $\mathrm{Bi}_{2} \mathrm{Se}_{3}$ phase. All $\mathrm{Bi}_{2} \mathrm{Se}_{3}$ films were polycrystalline with a preferential orientation along the [001] direction, corresponding to the direction of a trigonal axis $C_{3}$ in the $\mathrm{Bi}_{2} \mathrm{Se}_{3}$ crystal. The films exhibited $n$-type conductivity, like the initial $\mathrm{Bi}_{2} \mathrm{Se}_{3}$ crystal.

It was shown that as the film thickness increases up to $d \sim 100 \mathrm{~nm}$, the grain size $D$ and film roughness $h$ remain practically the same, being equal to $D=75 \pm 5 \mathrm{~nm}$ and $h=2.5 \pm 0.5 \mathrm{~nm}$. In the thickness range from $\sim 100$ to $\sim 250 \mathrm{~nm}, D$ and $h$ increase, however under further increase in $d$, the grain size and roughness practically cease to change.

The results obtained in this work show that using relatively simple and inexpensive method of thermal evaporation of bismuth selenide in vacuum and selecting optimal technological parameters, one can prepare thin $n-\mathrm{Bi}_{2} \mathrm{Te}_{3}$ films of a sufficiently good quality.

Acknowledgments. This work was supported by the Ukrainian Ministry of Education and Science (Projects No. M3925 and M0625). 


\section{References}

1. H.J.Goldsmid, Introduction to Thermoelectricity, Springer-Verlag, Berlin, Heidelberg, Germany (2016). DOI: https://dx.doi.org/ 10.1007/978-3-662-49256-7.

2. Materials Aspect of Thermoelectricity, ed. by C.Uher, Boca Raton, CRC Press (2016).

3. Thermoelectrics Handbook: Macro to Nano, ed. by D.M.Rowe, Boca Raton, CRC Press, Taylor \& Francis Group (2006).

4. M.S.Dresselhaus, G.Chen, M.Y.Tang et al., Adv.Mater., 19, $1043 \quad$ (2007). DOI: http://dx.doi.org/10.1002/adma.200600527.

5. R.Venkatasubramanian, E.Siivola, T.Colpitts, B.O'Quinn, Nature, 413, 597 (2001). DOI: https://doi.org/10.1038/35098012.

6. M.Z.Hasan, C.L.Kane, Rev.Mod.Phys., 82, 3045 (2010). DOI: https://doi.org/10.1103/ RevModPhys.82.3045.

7. D.Culcer, Physica E, 44, 860 (2012). DOI: https://doi.org/10.1016/j.physe.2011.11.003.

8. L.Muchler, F.Casper, B.Yan et al., Phys. Stat. Sol. RRL, 7, 91 (2013).

9. D.Teweldebrhan, V.Goyal, M.Rahman et al., Appl.Phys. Lett., 96, 053107 (2010). DOI: https://doi.org/10.1063/1.3280078.

10. P.Ghaemi, R.S.K.Mong, J.Moore, Phys. Rev. Lett., 105, 166603 (2010).

11. J.H.Davies, The Physics of Low-Dimensional Semiconductors. An Introduction, Cambridge University Press, Cambridge, USA (1997). DOI: https://doi.org/10.1017/CBO9780511819070.

12. Yu.F.Komnik, Physics of Metal Films, Atomizdat, Moscow (1979) [in Russian].

13. E.I.Rogacheva, O.S.Vodorez, O.N.Nashchekina et al., J.Electron. Mater., 39, 2085 (2010).

14. E.I.Rogacheva, A.V.Budnik, A.Yu.Sipatov et al., Appl. Phys. Lett., 106, 053103 (2015). DOI: https://doi.org/10.1063/1.4907319.

15. E.I.Rogacheva, A.V.Budnik, A.G.Fedorov et al., J. Thermoelectricity, 2, 5 (2015).

16. E.I.Rogacheva, O.N.Nashchekina, A.V.Budnik et al., Thin Solid Films, 612, 128 (2016).

17. A.V.Budnik, E.I.Rogacheva, V.I.Pinegin et al., J.Electron. Mater., 42, 1324 (2013). DOI: http://dx.doi.org/10.1007/s11664-012-2439-1.

18. A.V.Budnik, E.I.Rogacheva, A.Yu.Sipatov, J. Thermoelectricity, 4, 19 (2013).

19. K.J.John, B.Pradeep, E.Mathai, Sol. State Comm., 83, 501 (1992). DOI: https://doi.org/10.1016/0038-1098(92)90046-C

20. K.J.John, B.Pradeep, E.Mathai, Sol.State Comm., 85, 879 (1993).

21. D.Nataraj, K.Senthil, Sa.K.Narayandass, D.Mangalaraj, Cryst.Res.Technol., 34, 867 (1999).

22. D.Nataraj, K.Senthil, Sa.K.Narayandass, D.Mangalaraj, Indian J.Engineering and $\mathrm{Ma}$ terials Sciences, 6, 164 (1999).

23. D.Nataraj, K.Prabakar, Sa.K.Narayandass, D.Mangalaraj, Cryst.Res. Technol., 35, 1087 (2000).
24. V.T.Patil, Y.R.Toda, D.N.Gujarathi, Intern.J. Sci Engin Res, 5, 1220 (2014).

25. S.S.Fouad, A.Y.Morsy, H.M.Talaat, M.E.ElTawab, Phys. Stat.Sol.B, 183, 149 (1994). DOI:https://doi.org/10.1002/pssb.2221830111.

26. N.N.Ojha, J.P.Sharma, A.Kumar, Radial Chalcogenide Lett., 11, 281 (2014). http://chalcogen.ro/281_Ojha.pdf

27. A.A.El-Shazly, M.I.El-Agrab, S.S.Fouad et al., Egypt.J. Solid., 14, 89 (1991).

28. L.J.Collins-McIntyre, W.Wang, B.Zhou et al., Phys. Stat. Sol. B, 252, 1334 (2015). DOI: https://doi.org/10.1002/pssb.201552003.

29. L.He, F.Xiu, Y.Wang et al., J.Appl.Phys., 109, 103702 (2011).

30. X.F.Kou, L.He, F.X.Xiu et al., Appl.Phys. Lett., 98, 242102 (2011).

31. N.Bansal, Y.S.Kim, M.Brahlek et al., Phys. Rev.Lett., $109, \quad 116804 \quad$ (2012). DOI: https://doi.org/10.1103/PhysRevLett.109.1 16804.

32. A.A.Taskin, S.Sasaki, K.Segawa, Y.Ando, Phys. Rev. Letters, 109, 066803 (2012).

33. Z.Chen, T.A.Garcia, J.De Jesus et al., J.Electron.Mater., 43, 909 (2014). DOI: https://doi.org/10.1007/s11664-013-2890-7.

34. J.Chen, H.J.Qin, F.Yang et al., Phys.Rev. Lett., 105, 176602 (2010). DOI: https://doi.org/10.1103/PhysRevLett.105.1 76602 .

35. W.J.Wang, K.H.Gao, Z.Q.Li, Scientific Reports, 6, 25291 (2016). DOI: https://doi.org/10.1038/srep25291.

36. P.H.Le, K.H.Wu, C.W.Luo, J.Leu, Thin Solid Films, $\mathbf{5 3 4}, \quad 659 \quad$ (2013). DOI: https://doi.org/10.1016/j.tsf.2013.01.104.

37. N.D.Desai, V.B.Ghanwat, K.V.Khot et al., $J$. Mater.Sci.:Mater.Electron., 27, 2385 (2016). https://doi.org/10.1007/s10854-015-4036-6.

38. Z.Sun, S.Liufu, R.Liu et al., J.Mater.Chem., 21, 2351 (2011).

39. K.Kadel, L.Kumari, W.Z.Li et al., Nanoscale Res. Lett., 6, 57 (2011).

40. X.Li, K.Cai, H.Li et al., Int.J.Miner. Metall. Mater., 17, 104 (2010). DOI: https://doi.org/ 10.1007/s12613-010-0118-x.

41. R.Sankapal, C.D.Lokhande, Mater.Chem. Phys., 73, 151 (2002). DOI: https://doi.org/ 10.1016/S0254-0584(01)00362-5.

42. Powder Diffraction File, Joint Committee on Powder Diffraction Standards, ASTM, Philadelphia, PA, 1967.

43. M.Ferhat, J.C.Tedenac, J.Nagao, J.Cryst. Growth, 218, 250 (2000).

44. M.Ferhat, B.Liautard, G.Brun et al., J.Cryst. Growth, 167, 122 (1996). DOI: https://doi.org/ 10.1016/0022-0248(96)00247-3.

45. J.C.Tedenac, S.Dal Corso, A.Haidoux et al., Mat. Res. Soc. Symp. Proc., 545, 93 (1998).

46. I.Novikov. Theory of Metal Thermal Treatment, Metallurgia, Moscow (1978) [in Russian].

47. B.S.Jariwala, D.V.Shah, V.Kheraj, J.NanoElectron. Phys., 3, 101 (2011). 